\title{
PEMANFAATAN Website Untuk ManaJEMEN INFORMASI PENELITIAN PETERNAKAN KOTA BATU
}

\author{
Usman Nurhasan ${ }^{1}$, Rizky Alifian Lutfi ${ }^{2}$ \\ ${ }^{1}$ Usman Nurhasan, ${ }^{2}$ Rizky Alifian Lutfi, Teknologi Informasi, Politeknik Negeri Malang \\ Email :1'usmannurhasan@polinema.ac.id, ${ }^{2}$ rizkyalifian48@gmail.com
}

\begin{abstract}
Abstrak : Saat ini perkembangan teknologi sangat cepat maka dari itu perkembangan dalam memberikan informasi juga harus mengikuti zaman dalam jurnal ini akan dijelaskan bagaimana proses dalam pembuatan sebuah Sistem Informasi dimana nantinya Sistem Informasi tersebut berbasis website dan akan menggunakan platform wix untuk membantu dalam membuat website tersebut. Dalam Sistem Informasi ini akan membantu memberikan informasi dari Balai Besar Pelatihan Peternakan. Balai Besar Pelatihan Peternakan Kota Batu (BBPP) Kota Batu adalah salah satu lembaga pendidikan dalam bidang pertanian dan peternakan. BBPP Kota Batu melalui divisi diklat limbah dan hasil ikutan ternak membuat suatu diklat pengolahan limbah. Pelaksanaan diklat pengolahan limbah yang banyak menggunakan praktek memerlukan multimedia pembelajaran interaktif yang dapat membantu menyajikan materi dengan mudah dipahami. Multimedia pembelajaran interaktif dikembangkan dengan tujuan untuk menghasilkan produk yang berupa multimedia pembelajaran interaktif yang valid, yang akan menjadi alternatif dalam pencapaian tujuan pembelajaran yang ditentukan, serta dapat meningkatkan daya serap peserta diklat pengolahan limbah di BBPP Kota Batu. Dalam Pembuatan Sistem Informasi berbasis website ini digunakan platform wix, dimana platform tersebut sangat berguna dan mudah digunakan untuk admin dikarenakan fungsi untuk membuat website menggunakan drag and drop sehingga admin dapat membuat desain tampilan sesuai dengan kebutuhan.
\end{abstract}

Kata Kunci-BBPP, Kementan, Website, Wix, Sistem Informasi

\section{Pendahuluan}

$\mathrm{P}$ erkembangan teknologi saat ini telah berkembang sangat pesat dan membawa perubahan yang sangat besar karena dengan teknologi tersebut informasi bisa didapat dengan cepat, akurat dan tidak terbatas oleh waktu dan tempat. Salah satu faktor yang berkembang dalam perkembangan teknologi adalah di bidang pertanian dan peternakan yang akan memberikan dampak besar terhadap kebutuhan masyarakat dan dapat memberikan informasi - informasi yang sesuai dengan kebutuhan khususnya melalui teknologi internet. Dengan bantuan perkembangan teknologi ini maka informasi yang diberikan akan lebih cepat dikarenakan pada generasi milenial yang serba cepat saat ini kebutuhan informasi melalu sarana website sangat berguna dan mudah diakses dari manapun,

Saat ini Indonesia merupakan Negara beriklim tropis dimana sebagian besar masyarakatnya merupakan seorang petani ataupun peternak, maka dari itu potensi untuk mengembangakn website dari Balai Besar Pelatihan Peternakan ini sangat dibutuhkan sehingga dapat berguna untuk menambah informasi dan berita terbaru tentang kegiatan dan penelitian yang ada di Balai Besar Pelatihan Peternakan ini salah satunya yang ada di Kota Batu.

Balai Besar Pelatihan Peternakan berdiri tahun 1977, awalnya bernama Regional Dairy Training Centre (RDTC) yang dibentuk atas kerjasama pemerintah Indonesia dan pemerintah Belanda yang bergerak dalam bidang pelatihan bidang peternakan dengan tenaga ahli dari Belanda. Tahun 1982 RDTC melembaga menjadi Balai Latihan Pegawai Pertanian (BLPP).

Berdasarkan hal tersebut, maka penulis tertarik untuk mengembangkan solusi dari permasalahan yang ada dan menuangkannya pada penelitian yang berjudul "Sistem Informasi Website Balai Besar Pelatihan Peternakan Kota Batu".

Agar penelitian ini dapat terarah dan tercapai sesuai dengan tujuan yang diharapkan dalam penelitian, maka ada beberapa batasan masalah yaitu, masalah data informasi tentang pertanian dan peternakan yang tidak 
tersampaikan pada pengguna dan masalah penyajian data yang akurat dan sarana yang mendukung untuk menyajikan informasi yang terdapat pada Balai Besar Pelatihan Peternakan Kota Batu ini.

\subsection{Sistem Informasi}

\section{TinjauAn PUSTAKa}

Sistem Informasi (SI) adalah kombinasi dari teknologi informasi dan aktivitas orang yang menggunakan teknologi itu untuk mendukung operasi dan manajemen. Dalam arti yang sangat luas, istilah sistem informasi yang sering digunakan merujuk kepada interaksi antara orang, proses algoritmik, data, dan teknologi. Dalam pengertian ini, istilah ini digunakan untuk merujuk tidak hanya pada penggunaan organisasi teknologi informasi dan komunikasi (TIK), tetapi juga untuk cara di mana orang berinteraksi dengan teknologi ini dalam mendukung proses. [1](Jogiyanto, 2009)

Menurut John F Nash pengertian sistem informasi adalah kombinasi dari beberapa manusia, alat teknologi atau fasilitas, media, pengendalian dan prosedur yang tujuannya menata jaringan komunikasi yang terstruktur, berkesinambungan, dan mempunyai sebuah aturan baku. Tujuannya adalah supaya dapat membantu pihak manajemen mengambil keputusan yang tepat berdasarkan pada pemakai data ekstern dan intern. [2](F Nash, 2013)

Sehingga dapat disimpulkan Sistem informasi harus dapat diandalkan sebagai sarana untuk memudahkan setiap pelaksanaan aktivitas sehingga kegiatan tetap akan berjalan cepat dan lancar sehingga meminimalisir kesalahan yang ada, dan penyajian informasi yang akan diberikan akan menjadi lebih baik dan terstruktur

\subsection{Website}

Website atau situs dapat diartikan sebagai kumpulan halaman yang menampilkan informasi data teks, data gambar diam atau gerak, data animasi, suara, video dan atau gabungan dari semuanya, baik yang bersifat statis maupun dinamis yang membentuk satu rangkaian bangunan yang saling terkait dimana masing masing dihubungkan dengan jaringan - jaringan halaman (hyperlink). [3](www.martianrecords.com, 2018)

Definisi secara umum, website adalah kumpulan dari berbagai macam halaman situs yang terangkum di dalam sebuah domain atau subdomain, yang berada di dalam WWW (World Wide Web) dan tentunya terdapat di dalam Internet. Halaman website biasanya berupa dokumen yang ditulis dalam format Hyper Text Markup Language (HTML). [4](Williams, 2002)

Sehingga dapat diartikan website adalah sebuah kumpulan halaman pada suatu domain di internet yang dibuat dengan tujuan tertentu dan saling berhubungan serta dapat diakses secara luas melalui halaman depan (home page) menggunakan sebuah browser.

\subsection{HTML 5}

HTML5 adalah singkatan Hyper Text Markup Language Versi 5, HTML5 merupakan sebuah teknologi penerus dari generasi sebelumnya yang dikeluarkan oleh W3C (World Wide Web Consortium) dan WHATWG (Web Hypertext Application Technology Working Group). dengan tambahan feature- feature baru untuk memperbaiki dan melengkapi dari HTML versi sebelumnya. [5](Hagino, 2013)

HTML5 merupakan sebuah bahasa yang terstruktur dan menampilkan isi dari World Wide Web, sebuah teknologi inti dari Internet. HTML5 adalah revisi kelima dari HTML dan hingga bulan Juni 2011 masih dalam pengembangan. Dimana tujuan utama pengembangan HTML5 adalah untuk memperbaiki teknologi HTML agar mendukung teknologi multimedia terbaru, mudah dibaca oleh manusia dan juga mudah dimengerti oleh mesin. HTML5 merupakan hasil proyek dari W3C (World Wide Web Consortium dan 
WHATWG ( Web Hypertext Application Technology Working Group ). Dimana WHATWG bekerja dengan bentuk web dan aplikasi dan W3C merupakan pengembang dari XHTML 2.0 pada tahun 2006, kemudian mereka memutuskan untuk bekerja sama dan membentuk versi baru dari HTML.[6](Hickson \& Hyatt, 2008)

Dapat disimpulkan pada HTML versi yang lama masih menggunakan bahasa dan model lama pada HTML 5 sendiri merupakan pembaruan dari versi HTML sebelumnya dimana pada HTML 5 ini memiliki banyak keunggulan salah satunya mendukung form control terbaru misalnya tanggal dan waktu, email, nomor, range, tel, url, pencarian, dll

\subsection{WIX}

Wix.com adalah platform pengembangan web berbasis awan yang memungkinkan penggunanya membuat situs web HTML5 dengan cara drag and drop. Pengguna dapat menambahkan berbagai fitur seperti tautan media sosial, perdagangan elektronik, formulir kontak, pemasaran surel, dan forum komunitas ke situs mereka menggunakan beragam aplikasi Wix dan aplikasi pihak ketiga.Wix dibangun dengan model bisnis freemium. Pendapatannya berasal dari layanan premium. Pengguna harus membeli paket premium supaya bisa menautkan situsnya ke alamat pribadi, menghapus iklan Wix, menambah fitur perdagangan elektronik, menambah penyimpanan dan kapasitas akses data, dan lain-lain[7] (Wix, 2016)

Dalam penelitian sistem informasi ini penggunaan platform WIX sangat penting dikarenakan keseluruhan penyimpanan sistem yang ada di website ini berada di wix, dan alasan dalam memilih platform ini dikarenakan mudah digunakan bagi semua kalangan dalam membuat website, batasanya hanya kreativitas yang dimiliki sehingga platform WIX ini sangat membantu dan berguna bagi website Balai Besar Pelatihan Peternakan Kota Batu ini.

\subsection{Balai Besar Pelatihan Peternakana Kota Batu}

Balai Besar Pelatihan Peternakan berdiri tahun 1977, awalnya bernama Regional Dairy Training Centre (RDTC) yang dibentuk atas kerjasama pemerintah Indonesia dan pemerintah Belanda yang bergerak dalam bidang pelatihan bidang peternakan dengan tenaga ahli dari Belanda. Tahun 1982 RDTC melembaga menjadi Balai Latihan Pegawai Pertanian (BLPP).

Pada era Kabinet Persatuan Nasional, BLPP berganti nama menjadi Balai Diklat Pertanian (BDP) hingga tahun 2002, sesuai dengan surat Keputusan Menteri Pertanian No. 334/Kpts/OT.210/5/02, BDP berganti nama menjadi Balai Diklat Agribisnis Persusuan dan Teknologi Hasil Ternak (BDAPTHT) sebagai Unit Pelaksana Teknis (UPT) yang secara organisatoris berada di bawah dan bertanggungjawab kepada Kepala Badan Pengembangan SDM Pertanian Departemen Pertanian. Tahun 2003 sesuai dengan Surat Keputusan Menteri Pertanian No. 489/Kpts/OT.160/10/2003, BDAPTHT meningkat statusnya menjadi Balai Besar Diklat Agribisnis Persusuan dan Teknologi Hasil Ternak (BBDAPTHT). Terakhir berdasarkan surat persetujuan Menteri Pendayagunaan Aparatur Negara Nomor : B/282/M.PAN/2/2007 tertanggal 7 Februari 2007 dan Peraturan Menteri PertanianNo. 19/Permentan/0T.140/2/2007 tanggal 19 Februari 2007 tentang Organisasi dan Tata Kerja Balai Besar Pelatihan Peternakan Batu maka BBDAPTHT retupoksi menjadi Balai Besar Pelatihan Peternakan (BBPP) Batu.[8](Kementan RI, 2014)

\section{Metode PENELITIAN}

Metode yang digunakan dalam pembuatan aplikasi data progress belanja Langsung ini mengacu pada metode Waterfall. Dalam metode Waterfall ini terdapat lima tahap, langkah-langkahnya adalah sebagai berikut : 


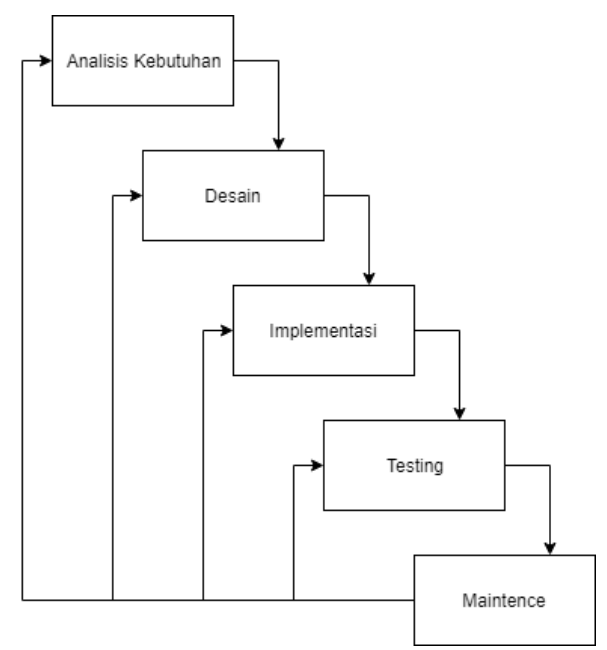

Gambar 3.1 Metode Waterfall

Dalam penerapan pada metode ini pembuatan sistem informasi ini penggunaan metode waterfall dapat memungkinkan untuk mengontrol perkembangan fase demi fase sehingga dapat meminimalisir kesalahan yang mungkin akan terjadi.

\subsection{Kebutuhan Analisis}

Spesifikasi kebutuhan sistem terdiri dari spesifikasi kebutuhan fungsional, kebutuhan non-fungsional, kebutuhan hardware, dan kebutuhan software:

\subsubsection{Kebutuhan Fungsional}

Berikut adalah kebutuhan fungsional dari aplikasi ini :

1. Melakukan login di wix.com

2. Mengelola website Balai Besar Pelatihan Peternakan Kota Batu,

3. Mengelola artikel atau post

4. Mengelola fitur fitur pada website

\subsubsection{Kebutuhan Non-Fungsional}

Berikut adalah kebutuhan non-fungsional dari aplikasi ini :

1. Data pada website meliputi profil, artikel, I-publik, E-publik dan inovasi

2. Aplikasi ini berbasis website dengan menggunakan platform WIX

3. Aplikasi ini digunakan untuk memberi informasi terhadap user atau pengguna

\subsection{Design}

Proses desain akan menerjemahkan syarat kebutuhan ke sebuah perancangan perangkat lunak yang dapat diperkirakan sebelum dibuat koding.

\subsubsection{Perancangan Sistem}

Sistem website Balai Besar Pelatihan Peternakan ini menggunakan platform wix.com, website ini merupakan sebuah website yang nantinya akan memberikan informasi mengenai seputar kegiatan Balai Besar Pelatihan Peternakan Kota Batu . Pada website ini hanya bisa diakses oleh admin yang telah terdaftar dan memiliki akun untuk melakukan login. Website Balai Besar Pelatihan Peternakan Kota Batu ini halaman utama dimana semua pengguna yang akan mengakses website ini akan melihat informasi - informasi yang terbaru, di halaman utama juga terdapat sub- menu yang dapat mengkases banyak pilihan informasi serta pendaftaran untuk peserta diklat. Kemudian Admin, adalah fitur yang dimiliki oleh wix.com dimana pengguna yang 
memegang username dan password akun website ini dapat melakukan apa saja mulai dari mengatur desain template, mebuat konten, menambahkan informasi seputar Balai Besar Pelatihan Peternakan, serta menambahkan artikel, sehingga kendali sepenuhnya website tersebut ada di tangan Admin. Kemudian Admin memeliki fungsi yang dapat menambahkan video yang dapat diputar dihalaman galeri sehingga membuat konten yang ada di dalam website dapat lebih menarik. Admin juga dapat melihat feedback atau saran masukan dari user yang melihat website tersebut dan juga ada kolom untuk memberikan komentar terhadap artikel atau berita yang sudah di upload dan juga dapat membalas feedback tersebut. Dari sisi user atau pengguna mereka dapat melihat informasi - informasi yang ada di dalam website Balai Besar Pelatihan Peternakan tersebut mulai dari profil balai, sejarah balai, informasi untuk diklat, galeri, informasi publik dan lain sebagainya. User juga dapat memberi feedback atau masukan terhadap website tersebut apakah website tersebut sempurna, baik, atau kurang dan dapat ditambahkan komentar sehingga membuat developer website tersebut dapat terus mengembangkan website Balai Besar Pelatihan Peternakan Kota Batu.

\subsubsection{Desain WBS (Work Breakdown System)}

Work Breakdown Structure (WBS) adalah suatu metode pengorganisasian proyek menjadi struktur pelaporan hierarakis.

Pada desain tersebut dapat dijelaskan proses yang terjadi saat pengerjaan website Balai Besar Pelatihan Peternakan Kota Batu ini. Tahapan pertama adalah Analisis kebutuhan dimana analisis tersebut meliputi konten website yang dimaksud adalah data yang nantinya akan digunakan pada website. Berikut merupakan desain WBS dari sistem informasi website Balai Besar Pelatihan Peternakan Kota Batu.

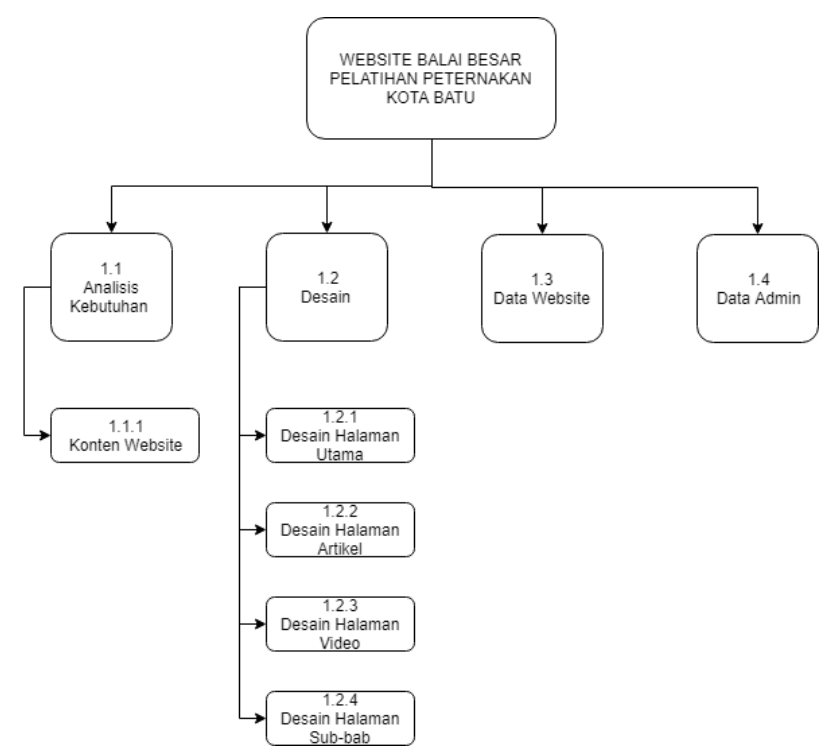

Gambar 3.2 Desain sistem WBS

Selanjutnya Desain desain adalah tampilan yang ada pada website tersebut dan meliputi tampilan desain halaman utama, tampilan desain halaman artikel, tampilan desain halaman video, tampilan desain sub-bab.

Kemudian selanjutnya adalah data website. Data website adalah proses memasukan data yang perlu digunakan pada website melalui analisis kebutuhan.

Terakhir adalah data admin, data admin adalah data untuk mengisi informasi tentang admin.

\subsubsection{Use Case Diagram}


Sistem Use Case diagram merupakan sebuah Teknik yang digunakan dalam pengembangan sebuah software atau sistem informasi untuk menangkap kebutuhan fungsional dari sistem yang bersangkutan,Pada gambar 3.2 ditunjukkan Use Case Diagram dari Website Balai Besar Pelatihan Peternakan Kota Batu. Dalam use case tersebut dijelaskan kegiatan yang dapat dilakukan oleh pengguna atau user dan admin.

Berikut adalah use case dari Website Balai Besar Pelatihan Peternakan Kota Batu

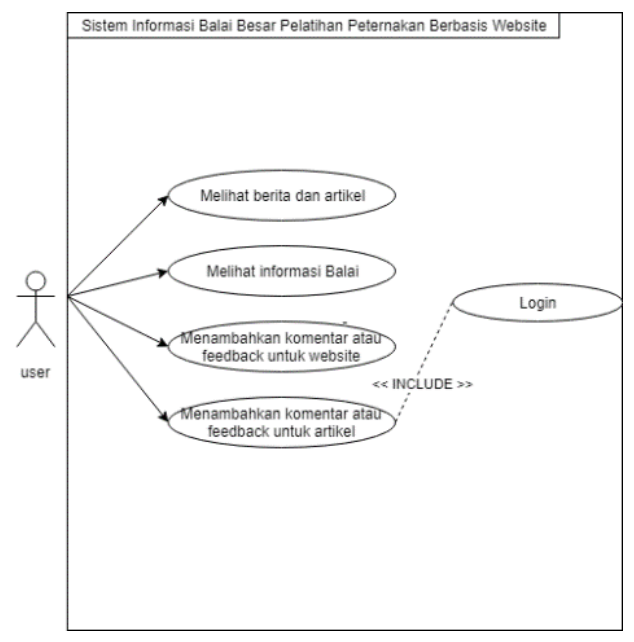

Gambar 3.3 Use Case Diagram User

Pengguna dapat melihat berita dan artikel yang telah disediakan di dalam website, pengguna juga dapat melihat semua informasi yang ada website Balai Besar Pelatihan Peternakan, Pengguna juga dapat memberikan feedback atau komentar terhadap website tersebut, dan juga menambahkan komentar terhadap berita atau artikel yang telah dibaca pada website Balai Besar Pelatihan Peternakan Kota Batu.

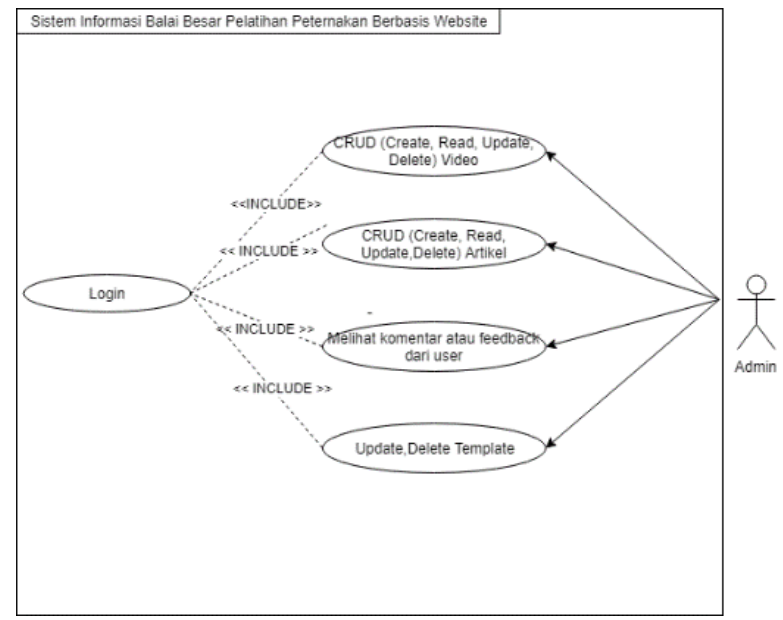

Gambar 3.4 Use Case diagram Admin

Kemudian dari Admin dapat mengelola data video berupa Create, Read, Update, Delete. Admin juga dapat mengelola data Artikel berupa Create, Read, Update, Delete. Kemudian admin dapat mengelola feedback dan komentar dari pengguna atau user, lalu mengelola template yang ada diwebsite berupa Update, dan Delete.

\subsubsection{Flowchart}


Flowchart adalah bagan-bagan yang mempunyai arus yang menggambarkan langkah-langkah penyelesaian suatu masalah.Flowchart merupakan cara penyajian dari suatu algoritma.

Pada Gambar 3.3 Flowchart ini menjelaskan kegiatan yang akan dilakukan oleh admin atau pengguna dalam Website Balai Besar Pelatihan Peternakan Kota Batu. Berikut merupakan flowchart dari sistem Website Balai Besar Pelatihan Peternakan Kota Batu.

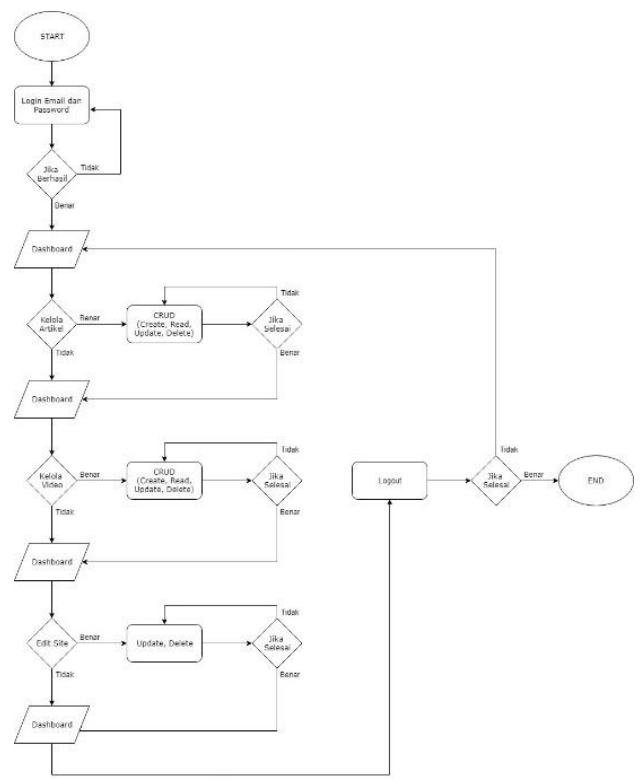

Gambar 3.5 Flowchart

Sistem ini dimulai dari admin harus melakukan login dengan menginputkan email dan password yang sesuai dengan akun yang telah terdaftar pada daftar admin. Setelah melakukan login, admin akan memasuki halaman utama atau beranda. Pada halaman utama, admin akan disuguhkan beberapa pilihan fitur. Pilihan fitur tersebut berupa tambah artikel, tambah video dan fitur untuk memperbarui atau mengedit site pada tampilan atau template website. Jika admin ingin melihat, menambahkan, mengedit atau menghapus artikel, maka admin harus ke halaman artikel Dan apabila telah selesai, bisa melakukan logout. Jika Admin ingin melihat, menambahkan mengganti atau menghapus video, maka admin dapat pergi ke halaman video, Jika admin ingin memperbarui tampilan website tersebut admin dapat pergi ke halaman edit site dan dihalaman tersebut telah disediakan berbagai pilihan fitur dan desain sehingga hanya dengan cara drag and drop admin dapat memperbarui dan menghapus tampilan dari website tersebut dan jika telah selesai admin dapat logout.

\subsection{Implementation}

Dalam tahap ini dilakukan pembuatan aplikasi. Pembuatan perangkat lunak dipecah menjadi modulmodul kecil yang nantinya akan digabungkan dalam tahap berikutnya. Selain itu dalam tahap ini juga dilakukan pemeriksaaan terhadap modul yang dibuat, apakah sudah memenuhi fungsi yang diinginkan.

\subsection{Testing}

Di tahap ini dilakukan uji coba di Balai Besar Pelatihan Peternakan untuk mengetahui apakah perangkat lunak yang dibuat telah sesuai dengan desainnya dan apakah masih terdapat kesalahan. Dengan dibantu oleh tim IT dari Balai Besar Pelatihan Peternakan Kota Batu.

\subsection{Maintenance}


Tahap ini dilakukan jika terdapat kesalahan atau kekurangan yang terdapat pada system informasi ini. Maka akan dilakukan pemeliharaan. Pemeliharaan termasuk dalam memperbaiki kesalahan yang tidak ditemukan pada langkah sebelumnya. Perbaikan yang dilakukan pada tahapan ini bisa saja kembali pada tahapan analisis kebutuhan sehingga perbaikan dapat memakan waktu lama karena harus sesuai metode yang digunakan yang berguna untuk meminimalisir kesalahan dalam pembuatan sistem informasi website Balai Besar Pelatihan Peternakan Kota Batu ini.

\section{HASIL DAN PEMBAHASAN}

Berikut merupakan hasil dari keseluruhan tampilan dari aplikasi data progress belanja langsung berbasis website.

\subsection{Halaman Login}

Halaman ini merupakan halaman yang diakses oleh admin untuk masuk ke dashboard website Balai Besar Pelatihan Peternakan Kota Batu. Dalam halaman ini, pengguna harus menyiapkan data berupa email dan password yang sesuai dengan akun yang sudah didaftarkan untuk melakukan login. Berikut merupakan tampilan halaman login dan cara mengakses halaman ini dengan menggunakan platform wix sehingga admin login melalui halaman wix.

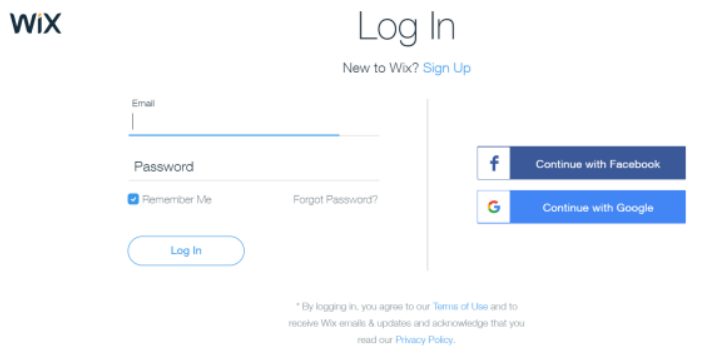

Gambar 4.1 Tampilan Login

Jika login berhasil maka user akan diteruskan pada halaman dashboard, jika tidak amka akan kembali lagi pada halaman login Ketika pengguna akan melakukan login, pengguna harus memasukkan email dan password sesuai dengan akun yang telah didaftarkan sebelumnya untuk melakukan login. Email dan password yang digunakan harus sesuai dengan akun yang telah terdaftar. Jika kolom email dan kolom password telah terisi semua dan benar, selanjutnya klik button login untuk melanjutkan proses memasuki halaman website.

\subsection{Halaman Admin}

Pada halaman ini admin sudah melalukan login dengan benar maka admin akan membuka tampilan website Balai Besar Pelatihan Peternakan Kota Batu ini dan Berikut merupakan hasil tampilan dari halaman Admin.

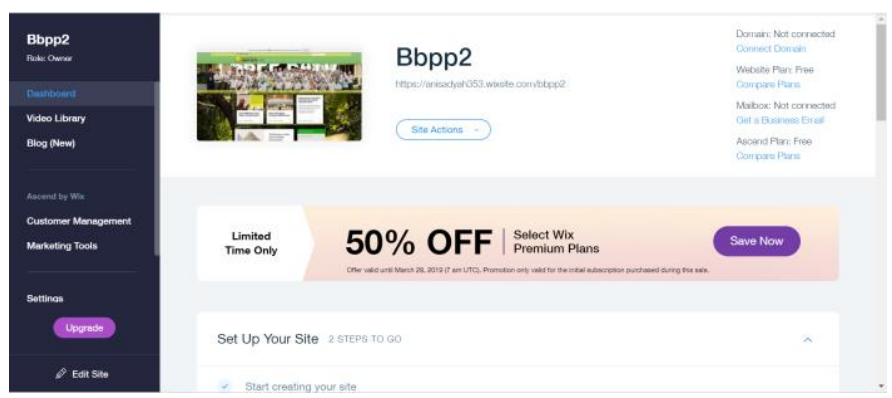

Gambar 4.2 Halaman Admin 
Halaman pada gambar diatas ini merupakan halaman awal ketika admin telah melakukan login dengan akun yang telah terdaftar. Dalam halaman ini juga terdapat beberapa fitur menu yang digunakan untuk menambah artikel, menambah video, dan mengubah website tersebut.

\subsection{Halaman Artikel}

Pada halaman ini akan ditampilkan artikel yang telah ditambahkan. Berikut merupakan hasil tampilan dari halaman Artikel

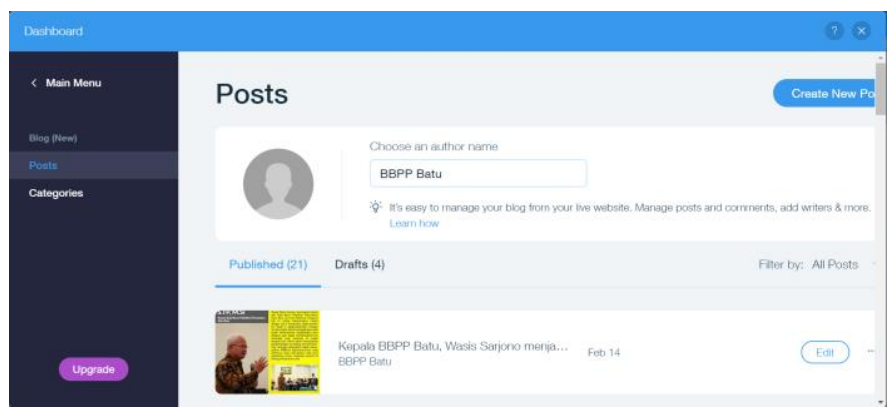

Gambar 4.3 Halaman Artikel

Semua artikel yang telah ditambahkan akan ditampilkan dihalaman utama website. Selain itu, admin juga bisa mengelola data dengan mengedit atau menghapus data yang telah ada. Semua data yang ada pada halaman ini sudah tersimpan di wix.com.

\subsection{Halaman Tambah Artikel}

Halaman ini merupakan sub menu dari tambah artikel. Halaman tambah artikel, memiliki fnngsi untuk melakukan penambahan artikel baru yang dilakukan oleh admin.

Berikut merupakan hasil tampilan dari halaman tambah artikel

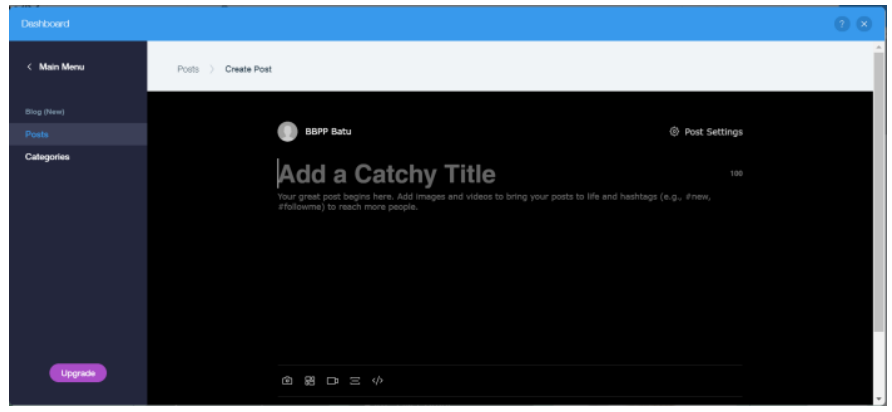

Gambar 4.4 Halaman Tambah Artikel

Untuk menambah artikel baru, yang harus dipersiapkan untuk melengkapi data sebagai admin yaitu berupa Judul, isi konten dan juga dapat ditambahkan gambar. Berikut merupakan tampilan setelah admin menambah data artikel.

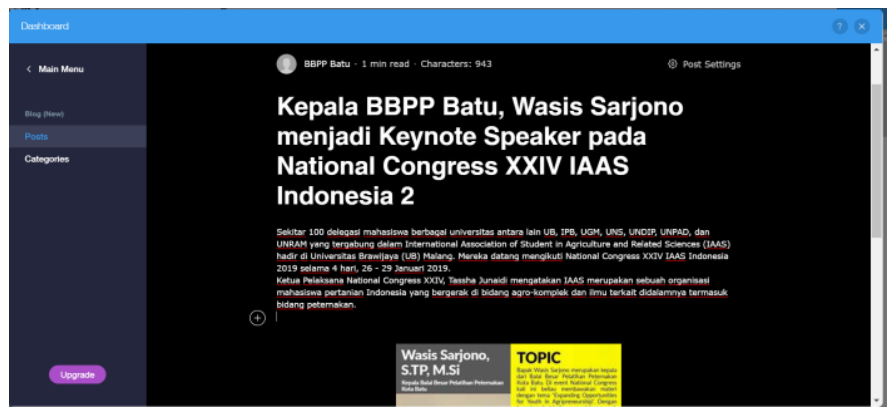




\section{Gambar 4.5 Halaman Pengisian Data Artikel}

Gambar 4.5 di atas menunjukkan fungsi dari edit artikel. Fungsi edit artikel berada pada kolom aksi yang berupa button. Edit artikel digunakan apabila admin ingin memperbarui data admin yang telah ditambahkan sebelumnya. Setelah itu terdapat juga button delete untuk menghapus sebuah artikel dan akan memunculkan notifikasi seperti gambar dibawah ini.

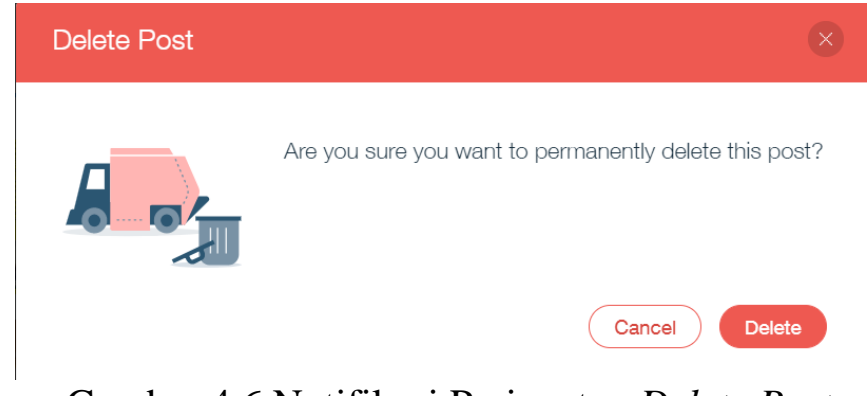

Gambar 4.6 Notifikasi Peringatan Delete Post

Gambar di atas merupakan pemberitahuan delete artikel. Pemberitahuan akan muncul ketika admin menekan button delete pada kolom aksi. Pemberitahuan ini muncul untuk memastikan, apakah admin benarbenar ingin menghapus data yang telah dipilih atau tidak. Apabila admin benar ingin menghapus data yang telah dipilih, maka pilih button Delete. Namun, jika admin ingin membatalkan hapus data, maka pilih button Cancel.

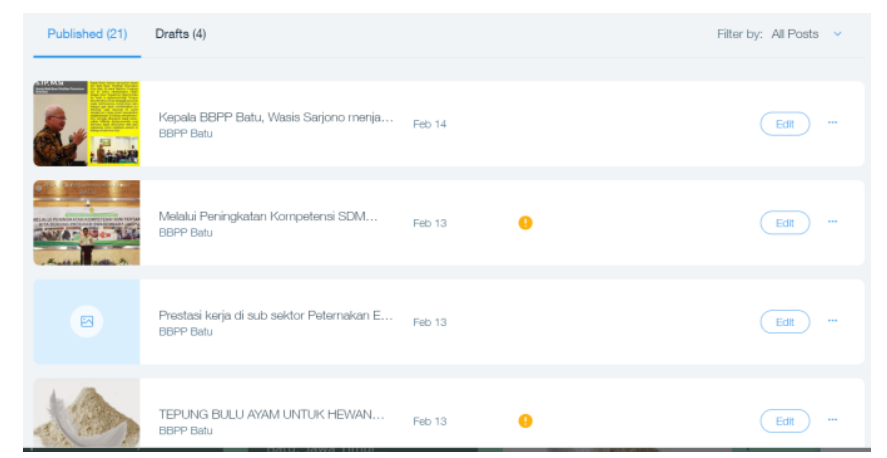

Gambar 4.7 Hasil Penambahan Artikel

Halaman ini merupakan hasil dari tambah Artikel. Ketika data yang telah ditambahkan oleh admin dinyatakan berhasil, maka data tersebut akan muncul pada daftar ini.

\subsection{Halaman Video}

Pada halaman ini akan ditampilkan video yang telah ditambahkan oleh admin. Semua video yang telah ditambahkan akan ditampilkan dihalaman galeri pada website. Selain itu, admin juga bisa mengelola data dengan mengedit atau menghapus data yang telah ada. Semua data yang ada pada halaman ini sudah tersimpan di wix.com, yang nantinya akan ditampilkan pada halaman video pada website Balai Besar Pelatihan Peternakan Kota Batu.

Berikut merupakan hasil tampilan dari halaman video 


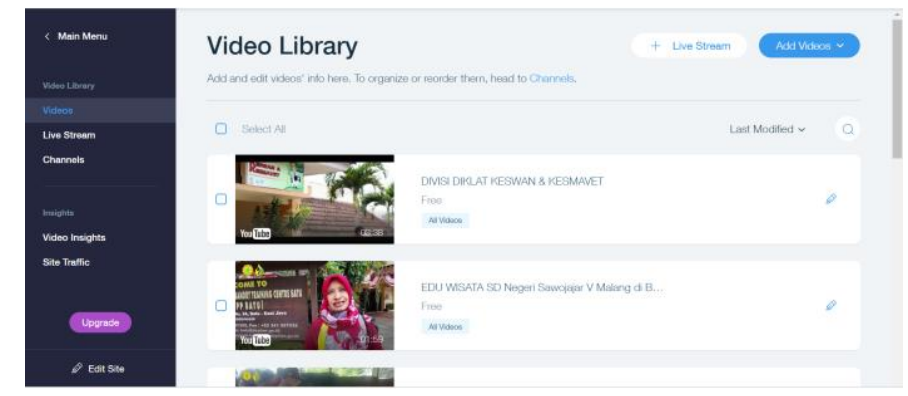

Gambar 4.8 Halaman Video

\subsection{Halaman Tambah Video}

Gambar dibawah menunjukan bagaimana cara menambah video yang ada pada halaman Video, Berikut Merupakan tampilan dari hasil menambah video

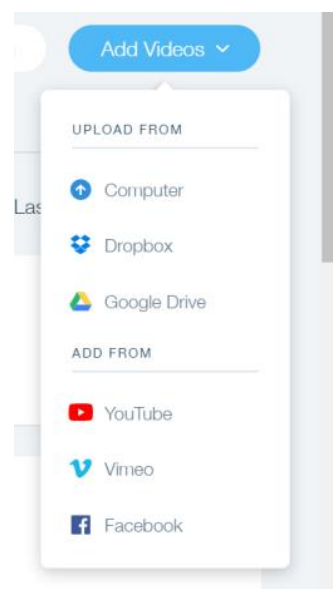

Gambar 4.9 Halaman Tambah Video

pada gambar tersebut ditampilkan bagaimana cara meng-upload sebuah video baru, digambar tersebut admin diberi pilihan untuk meng-upload video dari Computer, Dropbox, Google Drive, You Tube, Vimeo , dan Facebook. Sehingga admin dapat memeiliki berbagai cara dan pilihan untuk meng - upload video di website Balai Besar Pelatihan Peternakan Kota Batu.

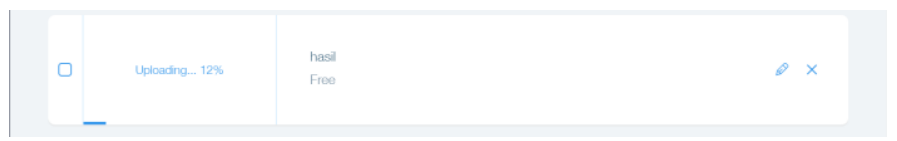

\section{Gambar 4.10 Proses Meng-Upload Video}

Pada gambar tersebut merupakan proses meng-Upload sebuah video baru lalu akan muncul sebuah notifikasi untuk dapat mengedit informasi pada video seperti gambar dibawah ini Setelah video selesai diupload maka video akan ditampilkan pada menu galeri dihalaman website Balai Besar Pelatihan Peternakan Kota Batu. Admin juga dapat menghapus sebuah video dengan memilih button delete pada kolom aksi. Setelah itu akan muncul pemberitahuan apakah admin akan menghapus video tersebut atau tidak, jika admin memilih delete maka admin akan menghapus video tersebut dan jika memilih Cancel maka admin akan dikembalikan pada halaman Video. Berikut adalah tampilan notifikasi untuk menghapus data video pada website Balai Besar Pelatihan Kota Batu 


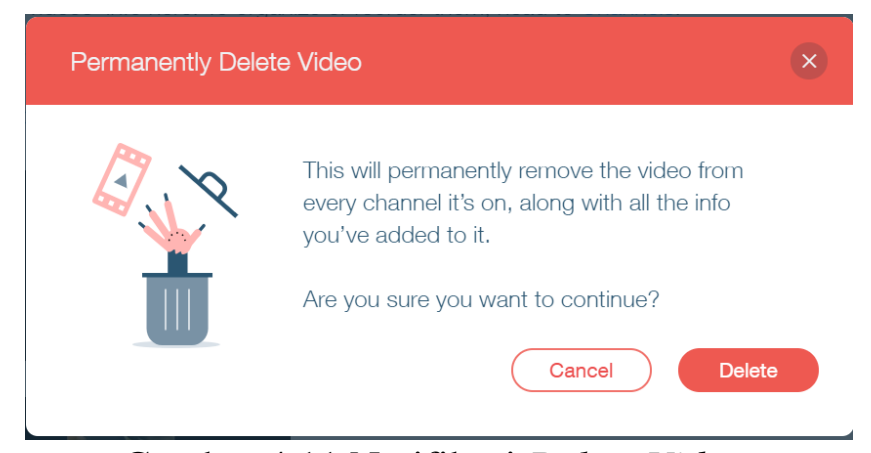

Gambar 4.11 Notifikasi Delete Video

Kemudian setelah video berhasil diupload pada halaman tambah video nantinya akan ditampilkan pada halaman website Balai Besar Pelatihan Peternakan Kota Batu dan juga pada halaman video yang nanti admin dapat mengedit atau mengubah video tersebut atau menghapus video tersebut. Berikut adalah tampilan halaman video jika video baru sudah ditambah.

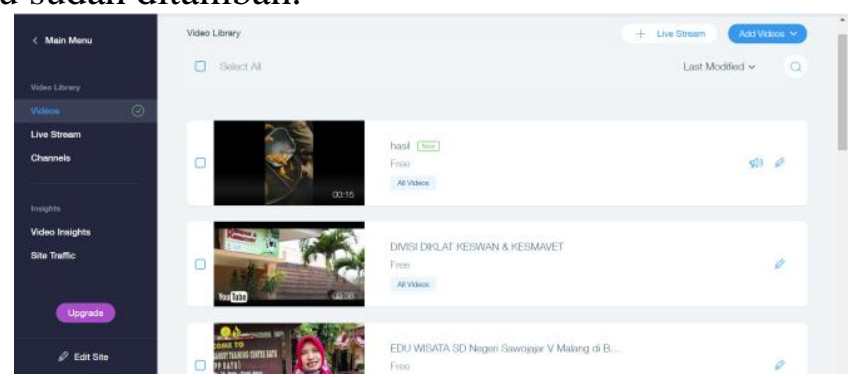

Gambar 4.12 Hasil tambah video

Pada gambar tersebut video yang baru saja diupload akan ditampilkan di atas sendiri pada list tersebut sehingga memudahkan admin untuk mengelola data video pada website Balai Besar Pelatihan Peternakan ini

\subsection{Meng-update Halaman Website}

Berikut adalah tampilan halaman untuk meng - update halaman pada website

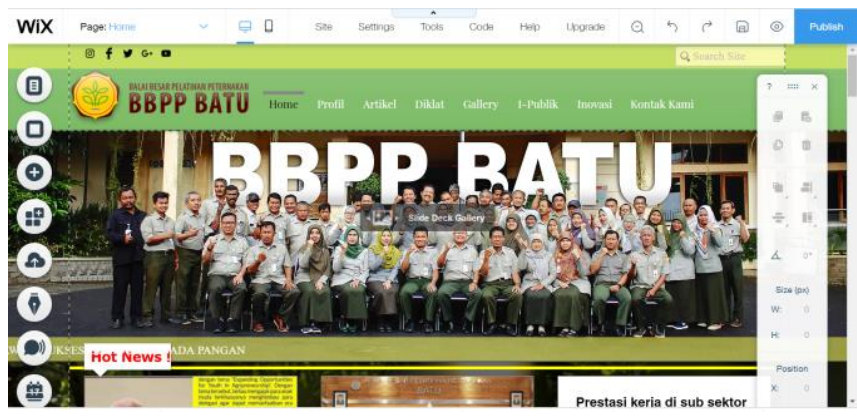

Gambar 4.13 Halaman Update Website

Pada Halaman ini admin dapat mengelola website tersebut terdapat berbagai macam tools yang dapat membantu admin dalam mendesain website Balai Besar Pelatihan Peternakan, cara menggunakan toolsnya hanya dengan drag and drop, dan setiap perubahan akan tersimpan otomatis pada halaman wix.

\subsection{Tampilan Halaman Website}

Tampilan Halaman Website merupakan tampilan utama yang selalu muncul saat mengakses halaman website Balai Besar Pelatihan Peternakan ini maka dari itu tampilan pada halaman utama harus dapat dipahami oleh user sehingga tampilan halaman utama akan menjadi lebih baik Berikut adalah tampilan halaman website 


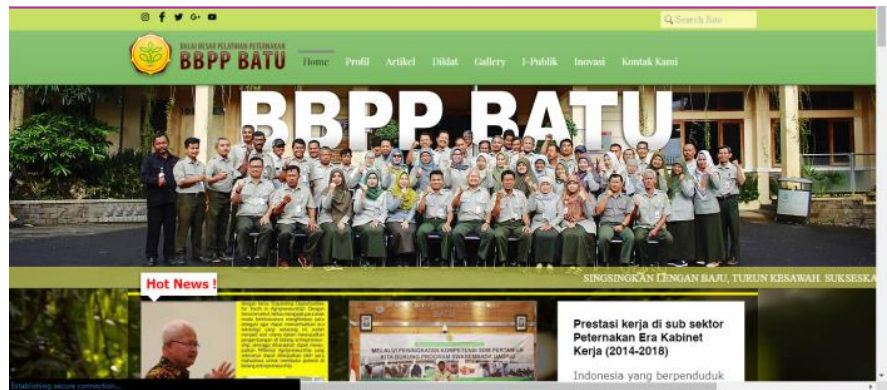

Gambar 4.14 Tampilan Halaman Website

Pada gambar diatas merupakan hasiil website Balai Besar Pelatihan Peternakan Kota Batu pada halaman tersebut ditampilkan informasi seputar Balai Besar Pelatihan Peternakan Kota Batu mulai dari Profil, Artikel, Galeri, Informasi Publik, dan lain sebagainya.

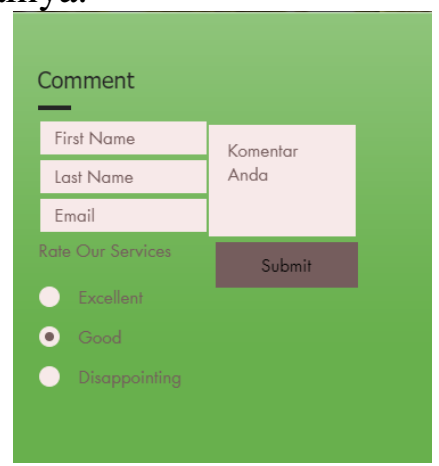

Gambar 4.15 Tampilan Feedback untuk website

Pada halaman ini juga user atau pengguna dapat memberikan komentar atau feedback terhadap website Balai Besar Pelatihan Peternakan Kota Batu. Pada gambar tersebut juga dijelaskan user dapat memberi masukan pada kolom yang disediakan dan juga memberi rating pada kolom pemilihan apakah website tersebut Excellent, good, atau Disappointing.

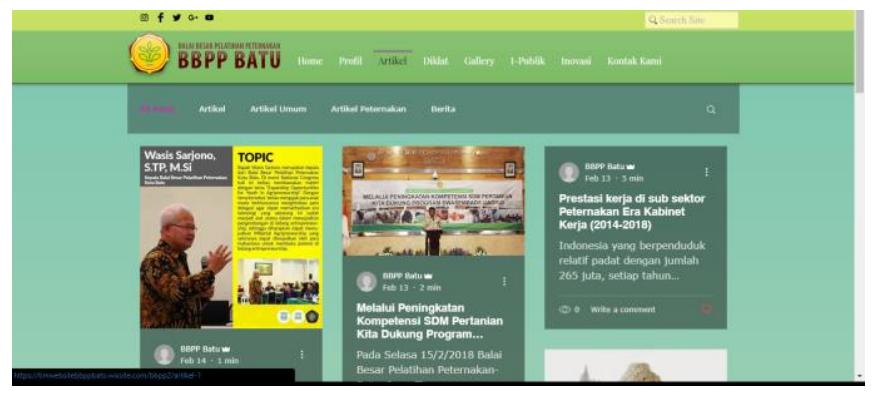

Gambar 4.16 Tampilan Halaman Artikel

Pada halaman website juga dapat ditampilkan artikel - artikel yang telah dibuat oleh admin dan dapat dibaca oleh user, user juga dapat memilih artikel untuk dibaca dan setelah itu user juga dapat memberikan komentar dan like terhadap artikel yang sudah dipost, sehingga dapat menjadi referensi untuk artikel selanjutnya.seperti gambar dibawah ini 


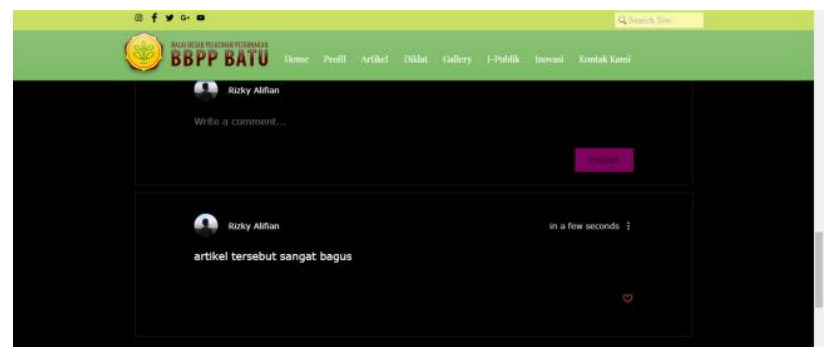

Gambar 4.17 Tampilan Tambah Komentar

Pada gambar tersebut user dapat memberi komentar dengan cara login dengan email atau tidak dengan menyertakan login, dan jika login dengan email maka nama pada komentar akan diterapkan

\section{KESIMPUlan DAN SARAN}

A. Kesimpulan

Berdasarkan hasil penelitian yang telah dilakukan Dari pengamatan tersebut dapat disimpulkan bahwa :

1. Masyarakat lebih mudah mengetahui kegiatan yang ada pada Balai Besar Pelatihan Peternakan Kota Batu

2. Penggunaan aplikasi Sistem Informasi Berbasis Website ini tidak hanya berguna bagi pegawai maupun staf yang ada pada Balai Besar Pelatihan Peternakan namun juga akan berguna bagi masyarakat luas

\section{DAFTAR PUSTAKA}

Jogiyanto, H. . (2009). Sistem Teknologi Informasi. In Sistem Teknologi Informasi. https://doi.org/10.1016/j.carbpol.2014.12.085

[2] F Nash, J. (2013). Pengertian sistem informasi. Pengertian Sistem Informasi. https://doi.org/10.1055/s2007-1014683

[3] www.martianrecords.com. (2018). Pengertian Web Browser, Sejarah, Fungsi Serta Contohnya Martinrecords.

[4] Williams, J. (2002). Website. British Journal of Occupational Therapy.

[5] Hagino, T. (2013). HTML5. The Journal of The Institute of Image Information and Television Engineers. https://doi.org/10.3169/itej.65.467

[6] Hickson, I., \& Hyatt, D. (2008). HTML 5. The World Wide Web Consortium.(W3C Working Draft). Online Verf\"ugbar Unter Http://Www. W3. Org/TR/Html5/, Zuletzt Gepr\\"uft Am.

[7] Wix. (2016). Free Website Builder | Create a Free Website | WIX.com.

[8] Kementan RI. (2014). Renstra Kementrian Pertanian Pertanian Tahun 2015 - 2019. Hari Aids Sedunia 2014. https://doi.org/351.077 Ind r 